\title{
The Influence Of Socio-Economic System On Academic Achievement Of Women Folk In Pakhtun Society
}

\author{
Jan Alam \\ \& \\ Sunehra Gul \\ Department of Social Work \& Sociology \\ Kohat University of Science \& Technology
}

\begin{abstract}
The study is aimed to test the association between socio-economic system and academic achievement of women folk in Kohat. The study is based on two variables i.e. independent variable (Socio-economic system) and dependent variable (academic achievement).Chi-square statistics is used to test the association between the two variables through cross tabulation. The total population of the study comprised of 344 boarder students in Girls Hostel 01 and Girls Hostel 02, KUST. A sample size of 228 is drawn on bases of criteria proposed by Sekaran (2010). The respondents are selected on the bases of systematic sampling technique. A questionnaire is distributed among respondents to reach to in-depth of the issue. The result shows that a significant association is found between family support, parental awareness, Purdah, class room culture and harassment where as the rest of the factors are found to have no significance with academic achievement. The study recommends that parental and family awareness may be developed, female students may be provided with efficient accommodation and transport facility, single gender educational institutions may be established to overcome the issue of harassment and violation of Purdah and monthly stipend may be paid/increase for women folk.
\end{abstract}

Keywords: Female, Socio-Economic Barriers, Academic Achievement.

$$
\begin{aligned}
& \text { تخخص }
\end{aligned}
$$

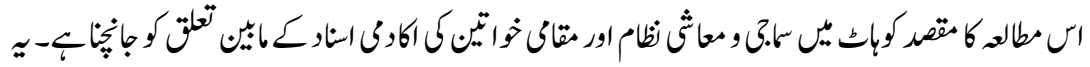

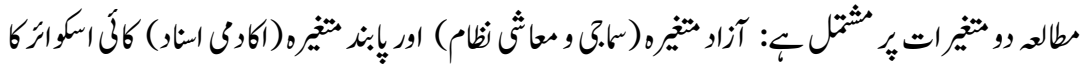

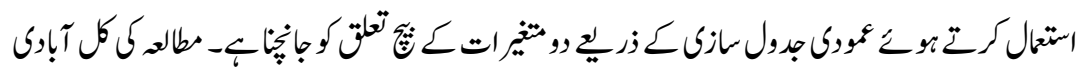

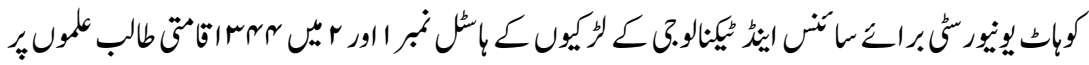

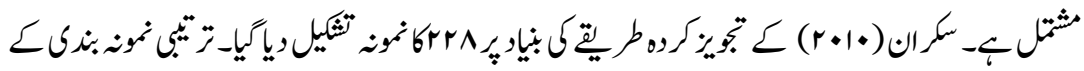

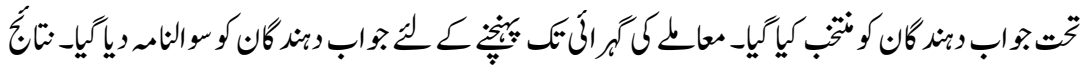

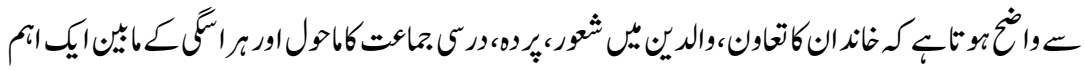

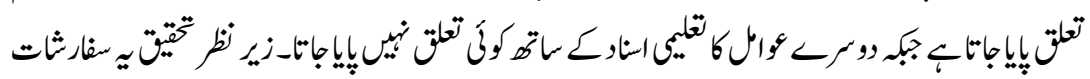




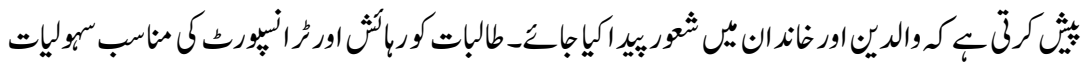

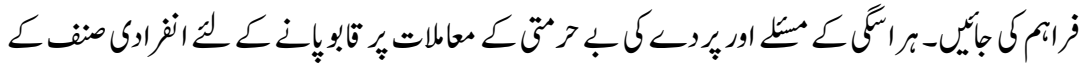

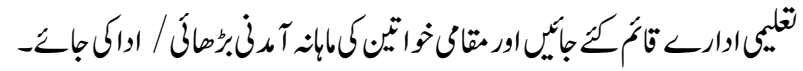

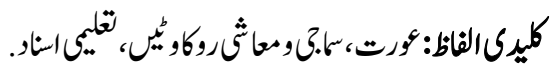

\section{Introduction}

Education is one of the important indicators of personality development as it improves human behavior, creates awareness and increases professionalism which empowers both male and female (PSLM, 2012). As a basic human right, education promotes economic growth as well and it increases human development index of a state (Okidi et al, 2004). However, to achieve these goals, it is essential to have more efforts which are directed to an increased ration of education especially in rural areas of Pakistan who cannot educate their children due to socio-economic constraints (Ashraf; Afzal; and Shurgeel, 2015).

The ratio of women education is least in Pakistan. A very little number of girls are enrolled at primary level (Memon, 2007). UNESCO (2012) also reported that Pakistan is among those countries who have poor literacy rate, the placement number of Pakistan is $130^{\text {th }}$ in International Human Indicators database places which is calculated for 141 countries on the basis of adult literacy (above 15 years) which also indicated that women's literacy rate was most considerable and was found to be quite lower than males. In Khyber Pakhtunkhwa it is only $36 \%$ for female and as it is $72 \%$ for male.

The economy and other resources such as wealth are managed by male members where there are rare opportunities for the investment of women capital and they are economically dependent. The employment, political, recreational and educational activities are gender biased, men are given the higher position against women. Women are not interested or do not take interest in the education and to make any contribution to it. Negative attitude and opposition of family members and social restrictions in certain situations also prevent women from involvement in educational activities (Khan et al., 2013). Female in the rural areas are the most neglected part of the population in their schooling especially those who belong to peasant household have more subordinate position as compare to male members of the family (Song et al., 2000).

Esere (2008) suggested that women can be empowered if they are provided adequate and functional forms of literacy. Such type of education will raise the level of self realization, awareness and socio-economic development. Memon 
(2007) believed that education provides a basis for smooth and secure working of human society. Education has profound effects on personality because it increases knowledge, competency, capability and skills (Memon; Joubish and Khurram, 2010).

\section{Social Factors}

There are a number of social factors that are related to poor performance, short attendance and drop out of girls from schools. Such factors included domestic chores, less time for study, lower priority of girls' education; inability or unwillingness to pay school expanses or other indirect costs (Mack, 2009) which unable women to get higher education.

Another factor of vital importance is Gender Based Violence (GBV) in educational institutions in which sexual harassment is more threatening both at secondary schools and higher educational level (Rwezaura, 1998) in most of the cases the perpetrators are reported to be male class fellows or in some cases teachers as well (Galla et. al, 1998). Mack (2009) also found that physical or any form of sexual aggression lessens girls' entrance into educational institutions. Hallam (1994) reported that the identified forms of sexual violence included oral abuses, cartooning, black mailing, pounding and raping. Parents will be unwilling to send their daughters to such educational institutions. Odaga and Haneveld (1995) recommended that the inculcation of female teachers in educational institution will create role models for girls as well as for their safety, which will lower the misperception of female students as well parents

Furthermore teaching methodology, gender based curriculum and classroom culture also affect women academic achievement. Such type of school environment also affects the survival of girls and increases the gender gap in education. The imbalanced attitude of teacher also effect girl education negatively. Besides, most of the people do not send their girls to far flung/ distant schools, colleges and universities (Kinyanjui, 1993; World Bank, 1992).

Physical security in some institution is reported to be poor who also limits women participation in education. Women folk need to be secured socio-culturally as well as financially (Colin \& Nadine, 1997). It is believed that male member of the family are preferred as compare to female due to the idea that men are physically strong and can defend themselves. Most of the societies are gender biased in decision making, economic and educational opportunities, and political and other fundamental rights and opportunities (Brock \& Cammish, 1993). Therefore it is necessary to secure women against physical violence, privacy and socio-cultural biasness (Herz et al., 1991; Njau \& Sheila, 1998). 
Some parents are unaware of the importance of girls' education so they do not want to educate their daughters which cause less enrolment of girls in schools (Odaga \& Heneveld, 1991). Cammish and Brock (1994) Davison and Kanyika (1992) found that parents prefer household activities for their girls as compare to education. Women are confined to domestic chores such as bringing water and fuel wood, cooking and caring of younger siblings.

Masha (1994) believed that poor literacy is due to culture, religion, economy, early marriage and common hostile attitude towards women. Whereas Caldwell and Caldwell (2005) found that women face cultural constraints like Purdah ${ }^{1}$ system that prevent women from taking part in educational activities and rigid gender roles like household exclusive for females.

\section{Economic Factors}

Economy plays a significant role in over all development of human personality. It is believed that those parents who enjoy a high socio-economic status in society are more able to send their young children to school because they have easier access to all necessary resources for promoting and supporting their children whereas those families who are lacking financial resources are failed to promote and bear school expanses. Therefore with low socio-economic status makes students less equipped as compare to those having medium or high economic status (Memon, Joubish and Khurram, 2010).

Davison (1993) indicates male dominancy in inheritance is an important factor in resource benefit therefore boys are foremost beneficiaries. According to Odaga \& Heneveld (1995) and Njau \& Sheila (1998) the most important of these opportunities is direct costs of schooling, employment opportunities, socioeconomic status, parental/family investment behavior, the economic value of girls education, rural/ urban residence, decision making and property distribution.

Another important reason is that male education is perceived as investment and future asset, it will also benefit the entire household whereas female is likely to be dependent housewife and after marriage as she becomes her husband's property. Such misperception, lack of family and parental motivation and discouraging attitude keeps Pakhtun women away from education (Mack, 2009).

Herz (1991) believed that girls' education is also beneficial in the future, therefore parents needs to spend on their daughter's education also. Those societies in which education is not mandatory, parents fail to decide whether and how much to educate their daughters. The quality of education also falls where the cost of education is high especially those who suffer from poor income resources, may perceive that the expected returns may not justify the present expenditures. Girls 
in such societies seem to be more vulnerable and secluded because parents hesitate pay education expenses. Oxaal (1997) reported that the ratio of women education is lower and there is a wide gender gap especially in poor countries.

Adolescent girls are confronted with less access to financial capital and limited opportunities to gain the education, knowledge, and skills which is a barrier of economic advancement. They are not supported socially as well as financially due to the persistent community social values and norms. Girls in such societies are at the bottom of socio-economic ladder. They are lacking confidence, absence of social network and poor health outcomes (Fewer and Dunnining, 2013) which effects the whole family.

\section{Objectives of the Study}

1. To measure is the perception and attitude of community towards the educational need and legacy in relation to woman.

2. To find out socio-economic conditions is restricting woman academic achievement in Pakhtun society.

3. To put forward policy recommendations on the basis of findings of the study.

\section{Research Methodology}

The present study focused on socio-economic system and its association with academic achievement of female students at Kohat University of Science and Technology (KUST). The study is undertaken with the following methods and procedures.

\section{Population and Universe}

The universe is finite with internally heterogeneous groups consisted of Boarder Female students of KUST. The total numbers of female boarder students is 344 which are further divided into two strata as Girls Hostel No.1 and Girls hostel No.2.

\section{Sampling and Sample Size}

Kothari (2004) suggested that the size of sample should be optimum it may neither be excessively large, nor too small. A most favorable sample is one which necessitates efficiency, representativeness, reliability and flexibility. Keeping in view 228 respondents are chosen out of 344 by using the methodology designed by Sekaran (2010). 
The population is arranged on the on the basis of list provided by Provost Office. The respondents are approached through systematic random sampling technique. Every $i^{\text {th }}$ respondent (i.e. Room no.) is selected, the formula is as under

$\mathrm{K}=N / n$

Where; $\mathrm{K}=$ Sample interval

$\mathrm{N}=$ is total population

$\mathrm{n}=$ is required sample size.

Table: 1

Distribution of population and sample size

\begin{tabular}{|l|c|c|}
\hline Population & Population size & Sample Size \\
\hline Girls Hostel No.1 & 194 & 120 \\
\hline Girls hostel No. 2. & 150 & 108 \\
\hline Total & $\mathbf{3 4 4}$ & $\mathbf{2 2 8}$ \\
\hline
\end{tabular}

Source: Provost Office KUST, (2014).

\section{Data Collection}

A detailed questionnaire incorporating all desired aspects of the study is used to collect data. It is further checked through pre-test and the ambiguities are addressed before the final stage of data collection.

\section{Data Analysis}

We use Statistical Package for Social Sciences i.e. SPSS (20 Version) for data analysis. Bivariate analysis is carried between dependent (Academic achievement) and independent variables (Socio-economic system) by using Chi Square $\left(\chi^{2}\right)$. According to Kothari (2004) Chi Square $\left(\chi^{2}\right)$ test is of prime importance for a social scientist to test significance of association between dependent and independent variables. The Chi Square $(\chi 2)$ test is used while adopting the procedure outlined by McCall and Robert (1975).

$$
\chi^{2}=\sum_{i=1}^{r} \sum_{j=1}^{c} \frac{\left(O_{i j}-e_{i j}\right)^{2}}{e_{i j}}
$$

Where, "O $\mathrm{O}_{\mathrm{ij}}$ " is the observed frequency in the cell corresponding to the intersection of the $\mathrm{I}_{-}{ }^{\text {th }}$ row and $\mathrm{J}_{-}{ }^{\text {th }}$ column, " $\mathrm{r}$ " the number of rows and " $\mathrm{c}$ " the number of columns.

The formula simply directs one to take the square formulation of the frequencies for each cell, divided by the expected frequency. The resulting value is distributed as Chi Square with relevant degrees of freedom, calculated as follows.

$$
\text { d.f. }=(\mathrm{r}-1)(\mathrm{c}-1)
$$




\section{Results and Discussion}

Getting education is not an easier job especially when it is confronted with the issue of gender in traditional societies such as Pakhtun Society. Pakhtun women are strong, brave and confident enough as they face many hardships throughout their lives. They are deprived of the basic rights such as employment and education, which not only effect women folk but Pakhtun society as whole.

Women are custodians of their families. They have been from a very long time gifted with many family responsibilities. Traditionally they play different social roles such as caring their family members, maintenance of home, feeding of the family, preservation of family health and in some cases impart to home economy in suitable manner (i.e. Bread Earners). The simple suggestion of this reality is that the woman of today's age is not likely to play these roles efficiently unless she is equipped with sufficient education. Today women face lots of problems both inside and outside the educational institutions. The study reveals that;

A significant $(\mathrm{p}<0.003)$ relationship is detected between family role and academic achievement. Family structure of the research area shows that it is male dominated and composed of all blood relatives i.e. father, mother, brother/s, sister/s and other blood relatives. The research reveals that the role of these members in educating the female member of the family is vital. It has both positive and negative impacts on women education. The research finds are inline Mack (2009); Ogada and Heneveld (1991) and Khan et al (2013).

The relationship $(\mathrm{p}<0.004)$ is found significant between parental role and academic achievement. The result depicts parental role is important in girl education as in most of the families of the research area the power of decision making is vested in parent mainly father. The decision of father or in some cases mothers' decision is final. No other member of the family can go beyond it, which may be significant in providing education to their daughter/s. The research finding is similar to Mack (2009); Kinyanjui (1993) and World Bank (1992).

A non significant $(p<0.149)$ relation is observed between self awareness and academic achievement. The research depicts that women of the research area knows the importance of education. They are motivated and self aware of the needs and importance of education. The result is in consonance with Camish and Brike (1994) and Njau and Wamahiu, (1998).

Priority of male over female and academic achievement shows a non significant $(p<0.136)$ relation. It reveals that most of the respondents of the study area have no discrimination in their families. One of the reasons could be that all the respondents are getting university level of education, which is an indicator that 
their families do not discriminate in terms of education. The finding is incongruent with Herz (1991) and Mack (2009).

Similarly a non significant $(\mathrm{p}<0.168)$ relation is extracted between domestic chores and academic achievement and a non significant $(\mathrm{p}<0.341)$ relationship between less time for study and academic achievement respectively. The study findings suggest that respondents of the study have no barriers such as domestic chores as they are boarder students. They have enough time for study at hostel. They have the opportunity to manage their activities especially off time study according to the available time. The research finding is dissimilar to Camish and Brock (1994) and Davison and Knayika (1992).

The study shows a significant $(\mathrm{p}<0.005)$ relation between distance from educational institution and academic achievement. It could be deduced from the findings that it is not easy for women of distant areas to approach to the educational institution. Besides, there are socio-cultural barriers that confine women to home, if there is no nearby educational institution. The research result is same as Masha (1994) and Khan et al. (2013).

Similarly a significant relation is found between violation of Purdah, class room culture and harassment and academic achievement. The relations are $(\mathrm{p}<0.004)$, $(p<0.002)$ and $(p<0.004)$ relationship respectively. The findings suggest that Purdah is an important aspect of social life in the study area. The mode of education at Higher level is co-education therefore most of the families associate it with violation of honor. Other key factors are class culture and the fear of harassment which are not acceptable to most of the families of the study area because of religious interpretation and Pakhtun code of ethics (i.e. Pakhtunwali ${ }^{2}$ ). The end result is similar to Caldwell \& Caldwell (2005) and Alam et al. (2014).

The relation between poor economic resources and academic achievement is traced as $(p<0.004)$. The result suggests that respondents of the study area are provided with resources to get education in a desired way. Similarly female from middle or high family may be more capable to get education. But a large number of Pakhtun women could not get enough education and even up to primary level so they remain ignorant, unskilled and unemployed due to poor economic status. Analogous result was found by Memon; Joubish and Khurram (2010), Song et al. (2000) and Naju \& Sheila (1998).

The association between job opportunity and academic achievement is $(p<0.05)$ relationship. Findings of the study suggest that women are fewer chances of jobs after completion of the degree/desired specialization because majority of them are confined to home after marriage, especially in the study area. A complementary result is found by Esere (2008) and Song et al. (2000). 
Table: 2

Association between socio-economic system and academic achievement

\begin{tabular}{|c|c|c|c|c|c|c|}
\hline \multirow{2}{*}{$\begin{array}{l}\text { Socio-economic } \\
\text { system }\end{array}$} & \multirow[t]{2}{*}{ Response } & \multicolumn{3}{|c|}{ Academic achievement } & \multirow[t]{2}{*}{ Total } & \multirow{2}{*}{$\begin{array}{c}\text { Test } \\
\text { statistics }\end{array}$} \\
\hline & & Positive & Negative & Undecided & & \\
\hline \multirow{5}{*}{ Family support } & Strongly agree & $105(46.06)$ & $13(5.7)$ & $4(1.75)$ & $122(53.50)$ & \multirow{5}{*}{$\begin{array}{c}\chi 2=11.137 \\
(.003)\end{array}$} \\
\hline & Agree & $68(29.8)$ & $3(1.31)$ & $0(00)$ & $71(31.14)$ & \\
\hline & Disagree & $5(2.19)$ & $1(0.43)$ & $0(00)$ & $6(2.63)$ & \\
\hline & St. Disagree & $6(2.63)$ & $0(00)$ & $11(4.82)$ & $17(7.45)$ & \\
\hline & Undecided & $8(3.50)$ & $4(1.75)$ & $0(00)$ & $12(5.26)$ & \\
\hline \multirow{5}{*}{$\begin{array}{l}\text { Parental } \\
\text { awareness }\end{array}$} & Strongly agree & $76(33.33)$ & $6(2.63)$ & $3(1.31)$ & $85(37.28)$ & \multirow{5}{*}{$\begin{array}{c}\chi 2=4.021 \\
(0.004)\end{array}$} \\
\hline & Agree & $16(7.01)$ & $9(3.94)$ & $13(5.70)$ & $38(16.66)$ & \\
\hline & Disagree & $9(3.94)$ & $0(00)$ & $2(0.87)$ & $11(4.82)$ & \\
\hline & St. Disagree & $25(10.96)$ & $21(9.21)$ & $0(00)$ & $46(20.17)$ & \\
\hline & Undecided & $13(5.70)$ & $18(7.89)$ & $17(7.45)$ & $48(21.05)$ & \\
\hline \multirow[t]{5}{*}{ Self awareness } & Strongly agree & $48(21.05)$ & $26(11.40)$ & $22(9.64)$ & $96(42.10)$ & \multirow{5}{*}{$\begin{array}{c}\chi^{2}=3.341 \\
(0.149)\end{array}$} \\
\hline & Agree & $55(24.12)$ & $13(5.70)$ & $5(2.19)$ & $73(32.01)$ & \\
\hline & Disagree & $19(8.33)$ & $7(3.07)$ & $13(5.70)$ & $37(16.22)$ & \\
\hline & St. Disagree & $10(4.38)$ & $5(2.19)$ & $1(0.43)$ & $16(7.01)$ & \\
\hline & Undecided & $4(1.75)$ & $2(0.87)$ & $0(00)$ & $6(2.63)$ & \\
\hline \multirow{5}{*}{$\begin{array}{l}\text { Priority of male } \\
\text { education }\end{array}$} & Strongly agree & $36(15.78)$ & $18(7.89)$ & $34(14.91)$ & $90(39.47)$ & \multirow{5}{*}{$\begin{array}{c}\chi^{2}=4.842 \\
(0.136)\end{array}$} \\
\hline & Agree & $17(7.45)$ & $8(3.50)$ & $13(5.70)$ & $38(16.66)$ & \\
\hline & Disagree & 41(17.98) & $6(2.63)$ & $5(2.19)$ & $52(22.80)$ & \\
\hline & St. Disagree & $39(17.10)$ & $5(2.19)$ & $3(1.31)$ & $47(20.61)$ & \\
\hline & Undecided & $0(00)$ & $1(0.43)$ & $0(00)$ & $1(0.43)$ & \\
\hline \multirow[t]{5}{*}{ Domestic chores } & Strongly agree & $13(5.70)$ & $9(3.9)$ & $15(6.75)$ & $37(16.22)$ & \multirow{5}{*}{$\begin{array}{c}\chi^{2}=3.125 \\
(0.168)\end{array}$} \\
\hline & Agree & $10(4.3)$ & $8(3.5)$ & $14(6.14)$ & $32(14.03)$ & \\
\hline & Disagree & $60(26.31)$ & $19(8.33)$ & $4(1.75)$ & $83(36.40)$ & \\
\hline & St. Disagree & $40(17.54)$ & $16(7.01)$ & $5(2.19)$ & $61(26.75)$ & \\
\hline & Undecided & $12(5.26)$ & $3(1.31)$ & $0(00)$ & $15(6.57)$ & \\
\hline \multirow{5}{*}{$\begin{array}{l}\text { Less time for } \\
\text { study }\end{array}$} & Strongly agree & $61(26.75)$ & $12(5.26)$ & $23(10.08)$ & $96(42.10)$ & \multirow{5}{*}{$\begin{array}{c}\chi 2=4.331 \\
(0.341)\end{array}$} \\
\hline & Agree & $43(18.85)$ & $6(2.63)$ & $4(1.75)$ & $53(23.24)$ & \\
\hline & Disagree & $15(6.57)$ & $3(1.31)$ & $0(00)$ & $18(7.89)$ & \\
\hline & St. Disagree & $9(3.9)$ & $7(3.07)$ & $0(00)$ & $16(7.01)$ & \\
\hline & Undecided & $20(8.77)$ & $15(6.57)$ & $10(4.38)$ & $45(19.73)$ & \\
\hline & Strongly agree & $88(38.59)$ & $15(6.57)$ & $13(5.70)$ & $116(50.87)$ & $\chi 2=.315$ \\
\hline Educational & Agree & $39(17.10)$ & $6(2.63)$ & $8(3.50)$ & $53(23.24)$ & $(0.264)$ \\
\hline & Disagree & $19(8.33)$ & $7(3.07)$ & $13(5.70)$ & $37(16.22)$ & \\
\hline & St. Disagree & $11(4.82)$ & $9(3.9)$ & $0(00)$ & $20(8.77)$ & \\
\hline & Undecided & $2(0.87)$ & $0(00)$ & $0(00)$ & $2(0.87)$ & \\
\hline Violation of & Strongly agree & $113(49.56)$ & $8(3.50)$ & $6(2.63)$ & $127(55.70)$ & $\chi 2=10.924$ \\
\hline Purdah & Agree & $50(21.92)$ & $26(11.40)$ & $0(00)$ & $76(33.33)$ & (.004) \\
\hline & Disagree & $15(6.57)$ & $3(1.31)$ & $0(00)$ & $18(7.89)$ & \\
\hline & St. Disagree & $7(3.07)$ & $0(00)$ & $0(00)$ & $7(3.07)$ & \\
\hline & Undecided & $0(00)$ & $0(00)$ & $0(00)$ & $0(00)$ & \\
\hline Class room culture & Strongly agree & $143(62.71)$ & $10(4.38)$ & $0(00)$ & $153(67.10)$ & $\chi^{2}=13.52$ \\
\hline & Agree & $37(16.22)$ & $8(3.50)$ & $0(00)$ & $45(19.73)$ & $(0.002)$ \\
\hline & Disagree & $20(8.77)$ & $5(2.19)$ & $0(00)$ & $25(10.96)$ & \\
\hline & St. Disagree & $4(1.78)$ & $1(0.43)$ & $0(00)$ & $5(2.19)$ & \\
\hline & Undecided & $0(00)$ & $0(00)$ & $0(00)$ & $00(00)$ & \\
\hline Harassment & Strongly agree & $110(48.24)$ & $13(5.70)$ & $8(3.50)$ & $131(57.45)$ & $\chi^{2}=10.739$ \\
\hline & Agree & $56(24.56)$ & $7(3.07)$ & $0(00)$ & $63(27.63)$ & $(.004)$ \\
\hline & Disagree & $16(7.01)$ & $8(3.50)$ & $0(00)$ & $24(10.52)$ & \\
\hline & St. Disagree & $10(4.38)$ & $0(00)$ & $0(00)$ & $10(4.38)$ & \\
\hline & Undecided & $0(00)$ & $0(00)$ & $0(00)$ & $0(00)$ & \\
\hline Poor Economic & Strongly agree & $93(40.78)$ & $8(3.50)$ & $3(1.31)$ & $104(45.61)$ & $\chi^{2}=6.371$ \\
\hline Resources & Agree & $46(20.17)$ & $23(10.08)$ & $9(3.94)$ & $78(34.21)$ & $(.004)$ \\
\hline & Disagree & $9(3.94)$ & $1(0.43)$ & $0(00)$ & $10(4.38)$ & \\
\hline & St. Disagree & $13(5.70)$ & $6(2.63)$ & $8(3.50)$ & $27(11.84)$ & \\
\hline & Undecided & $6(2.63)$ & $3(1.31)$ & $0(00)$ & $9(3.94)$ & \\
\hline
\end{tabular}




\begin{tabular}{|l|l|c|c|c|c|c|}
\hline \multirow{3}{*}{$\begin{array}{l}\text { Absence of } \\
\text { employment } \\
\text { opportunities }\end{array}$} & Strongly agree & $103(45.17)$ & $16(7.01)$ & $20(8.77)$ & $139(60.96)$ & $\chi^{2}=9.136$ \\
\cline { 2 - 5 } & Agree & $40(17.54)$ & $8(3.50)$ & $0(00)$ & $48(20.05)$ & $(.005)$ \\
\cline { 2 - 6 } & Disagree & $14(6.14)$ & $5(2.19)$ & $0(00)$ & $19(8.33)$ & \\
\cline { 2 - 6 } & St. Disagree & $11(4.82)$ & $7(3.07)$ & $0(00)$ & $18(7.89)$ & \\
\cline { 2 - 6 } & Undecided & $4(1.78)$ & $0(00)$ & $0(00)$ & $4(1.78)$ & \\
\hline
\end{tabular}

\section{Conclusions}

The research reveals that socio-economic system is significantly associated with women education. Some of the important social norms are Pakhtunwali and Purdah. Besides, women education is not favourable due to coeducational institutions therefore women are confined to hold house activities. Another important thing that is deeply rooted idea in our society is that investment on boys' education is beneficial for the whole family. Family and parental awareness about female education is also important. Other important factors are poverty, distance from educational institutions and security problems negatively effect education.

\section{Recommendations}

1. Those strategies need to be encouraged that helps to develop mindset of parent/family develop regarding girls education.

2. To ensure Purdah and avoid harassment, consideration may be given to increase the number single-sex universities.

3. Better participation of women and expansion education and training women may can be achieved through efficient residential, transportation facilities and security facilities and special focus on primary education in rural areas.

4. Women may be provided with economic opportunities especially after getting a Degree so that they may prove themselves a "Role Model" for other women and their parents and families.

5. Girls may be respected and provided with secure treatment especially in co-educational institutions to build confidence and ensure their deep hearted attention to their study.

6. Provision/increase in stipend on monthly basis may be fruitful in overcoming the issues of educational expenses.

\section{End Notes}

1. The concept of Purdah is protection of female chastity, it is uncompromising and the matter of shame is attached it (Alam and Ali, 2013).

2. Pakhtunwali is an unwritten code of life of Pakhtun. All the norms and values are deeply rooted in Pakhtunwali (Alam et al, 2014). 


\section{References}

Alam, J., Ali, R, S., Shah, M. \& Jamal, H. (2014). Feuds: An Arena of Pakhtunwali and Violence among Pakhtun of Afridi Tribe, FWU Journal of Social Sciences, vol.8:02, pp.36-41.

Alam, J. \& Ali, R, S. (2013). Honor: An Uncompromised Feature of Afridi Tribe, Journal of Law and Society, University of Peshawar, Pakistan, vol.44:63, pp.115-127.

Ashraf, E., Afzal, Y, M. \& Shurgeel, K, H. (2015). A Review of Rural Women Education in Pakistan, Science International Journal, vol.27:1, pp.555559.

Brock, C. \& Cammish, N. (1993). Factors Affecting Female Participation in Education in Seven Developing Countries, Universities of Oxford and Hull Universities of Oxford and Hull 1997- Education Research Paper No. 09, 1993, p-96.

Caldwell, J. \& Caldwell, B, K. (2005). Family Size and Control by Infanticide in the Great Agrarian Societies of Asia. Journal of Comparative Family Studies, vol.36:2, pp.205-226.

Colin, B. \& Nadine, C. (1997) Factors Affecting Female Participation in Education in Seven Developing Countries - Education, Department for International Development (FODA). http://r4d.dfid.gov.uk/PDF/ Outputs/Misc-Education/paper09.pdf

Davison, J. (1993). School Attainment and Gender: Attitudes of Kenyan and Malawian. http://www.sdnp.org.mw/womens_voice/edupg4.htm

Davison, J. \& Kanyuka, M. (1992). Girls Participation in Basic Education in Development. 14/3. European Journal of Business and Social Sciences, vol.2:4, pp.25-31.

Esere, M, O. (2008). Effect of Sex Education Program on At-Risk Sexual Behaviour of School Going Adolescents in Ilorin Nigeria, African Health Sciences, vol.8:2, pp.120-125.

Fewer, S., J. Ramos \& D. Dunning. (2013). Economic Empowerment Strategies for Adolescent Girls: A Research Study Conducted for the Adolescent Girls' Advocacy and Leadership Initiative. Oakland, CA: Public Health Institute. 
Galla, B. M., Plummer, B, D., White, R., Meketon, D., D’Mello, S, K. \& Duckworth, A, L. (1998). The Academic Diligence Task (ADT): Assessing individual differences in effort on tedious but important school work, Contemporary Educational Psychology, vol.39:4, pp.314-325.

Hallam, S. (1994). Crimes without Punishment: Sexual Harassment and Violence against Female students in Schools and Universities in Africa. Discussion Paper No.4.London: African Rights.

Herz, B. (1991). Letting Girls Learn: Promising Approaches in Primary and Secondary Education. Washington .D.C. World Bank. http://go.worldbank.org/ ET4S6TEXY0.

Herz, B., Subbarao, K., Habib, M. \& Raney, L. (1991). Letting Girls Learn: Promising Approaches in Primary and Secondary Education. World Bank Discussion Paper No 113, Washington D.C.

Khan, H., Ali, A., Khan, R. \& Zia, A. Y. (2013). Social Constraints of Female Education in Pakhtoon Society, European Journal of Business and Social Sciences, vol.2:4, pp.25-31.

Kinyanjui, K. (1993). Enhancing Women's Participation in the Science Based Curriculum: The case of Kenya, The University of Michigan Press.

Kothari, C. R. (2004). Research methodology: Methods and techniques, New Age International (P) Limited, Publishers (New Delhi, India).

Kumar, R. (2005). Research Methodology: $2^{\text {nd }}$ Edition, A Step by Step Guide for Beginners, Sage Publication Ltd (London, UK).

Laura, M. (2009). Girls Getting to Secondary School Safely: Combating Genderbased Violence in the Transportation Sector in Tanz African Child Policy Forum. Born to High Risk: Violence against Girls in Africa.

Mack, L. (2009). Girls getting to Secondary School Safely: Combating Gender- Based Violence in the Transportation Sector in Tanzania, Academy for Educational Development (AED) http://files.eric.ed.gov/fulltext/ED537465.pdf.

Masha, G. I. (1994). Women's Access to Education. Issues of Tradition and Culture. A Paper Presented at the National Conference on Education Kano State College of Education, Kano. Master plan of Operations Country Programme of Co-operation Part 2 (2001). 
McCall \& Robert, B. (1975). Fundamental Statistics for Psychology: $2^{\text {nd }}$ Edition, Harcourt brace Jovanovich Inc, (New York, USA).

Memon, G, R. Joubish \& Khurram, M. (2010). Impact of Parental SocioEconomic Status on Students' Educational Achievements at Secondary Schools of District Malir, Karachi. Middle-East Journal of Scientific Research, vol.6:6, pp.678-687.

Memon, R, G. (2007). Education in Pakistan; The Key Issues, Problems and The New Challenges, Journal of Management and Social Sciences, vol.3:1, pp.47-55.

Naju. W. \& Sheila, W. (1998). The Costs of Dropout: Addressing the Issues: In Ann Cotton and Richard Synge, eds (1998). Cutting the Gordian Knot: The Benefits of Girls Education in Africa. Cambridge: CAMFED.

Odaga, A. \& Heneveld, W. (1995). Girls and Schools in Sub-Saharan Africa: From Analysis to Action. Washington D.C.: The World Bank.

Okidi, J., Ssewanyana, S., Bategeka, L. \& Muhumuza, F. (2004). Operationalizing Pro-Poor Growth: Uganda Case Study. Economic Policy Research Center, Kampala. Mimeo.

Oxaal, Z. (1997). Education and Poverty, A Gender Analysis, Report prepared for the Parents towards Educating Girls, International Journal of Education and Development, vol.26:2, pp.13-4. Washington .D.C (USA).

PSLM, (2012). Pakistan Social and Living Standards Measurement Survey. http://unesco.org.pk/education/documents/2013/pslm/PSLM_2011-12.pdf

Rwezaura, B. (1998). Competing Images of Childhood in the Social and Legal Systems of Contemporary Sub Saharan Africa. International Journal of Law, Polity and the Family, vol.12:3, pp.253-278.

Sekaran, U. (2010). Research methods for business, Hermitage Publishing Services, (USA).

Song, L. Sappleton and Knight, J. (2006). Why Do Girls in Rural China have Lower School Enrolment? World development Journal, vol.34:9, pp.163916. Southern Malawi, Comparative Education Review, 36/4. 
UNESCO, (2012). Why Pakistan Needs a Literacy Movement? http://unesco.org.pk/education/documents/publications/Why_Pakistan_Ne eds_Literacy_Movement.pdf. Retrieved on 07-01-2016

United Nations. (2005). Review of the Implementation of the Beijing Platform for Action and the outcome documents of the special session of the General Assembly entitled "Women 2000:gender equality, development and peace for the twenty-first century." Report of the Secretary-General. E/CN.6/2005/2, para. 144-5.

World Bank. (1992). Uganda Social Sector Strategy. No.10765-UG.Washington. D.C (USA).

Jan Alam is Lecturer in the Department of Social Work \& Sociology Kohat University of Science \& Technology, Kohat.

Sunehra Gul is Student in the Department of Social Work \& Sociology Kohat University of Science \& Technology, Kohat. 